\title{
Organochlorine pesticides and PCBs in fish from lakes of the Tibetan Plateau and the implications
}

\author{
Ruiqiang Yang ${ }^{\mathrm{a}}$, Yawei Wang ${ }^{\mathrm{a}}$, An Li ${ }^{\mathrm{b}}$, Qinghua Zhang ${ }^{\mathrm{a}}$, Chuanyong Jing ${ }^{\mathrm{a}}$, Thanh Wang ${ }^{\mathrm{a}}$, Pu Wang ${ }^{\mathrm{a}}$, \\ Yingming Li ${ }^{\text {a }}$, Guibin Jiang ${ }^{\mathrm{a}, *}$

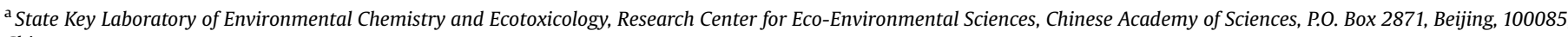 \\ China \\ ${ }^{\mathrm{b}}$ School of Public Health, University of Illinois at Chicago, Chicago, IL 60612, USA \\ Occurrence of POPs in higher-altitude lakes suggests that Tibetan Plateau acts as potential regional convergence zones for long-range atmo- \\ spheric transported contaminants.
}

\section{A R T I C L E I N F O}

\section{Article history:}

Received 13 October 2009

Received in revised form

29 January 2010

Accepted 6 February 2010

\section{Keywords:}

POPs

OCPs

Long-range atmospheric transport

Alpine lakes

Indian monsoon

\begin{abstract}
A B S T R A C T
High mountains may play significant roles in the global transport of persistent organic pollutants (POPs). This work aims to investigate the levels, patterns and distribution of semi-volatile organoclorine pollutants and to improve the understanding of the long-range atmospheric transport and fate of contaminants on the Tibetan Plateau. A total of 60 fish samples were collected from eight lakes located between 2813 and $4718 \mathrm{~m}$ above sea level across the Plateau. Concentrations of polychlorinated biphenyls (PCBs), organochlorine pesticides (OCPs) including dichlorodiphenyltrichloroethane and its metabolites (DDTs), hexachlorocyclohexanes (HCHs) and hexachlorobenzene (HCB) were measured in fish muscle. The results showed that concentrations of DDT, HCH and HCB were comparable to or lower than those found in remote mountains of Europe, Canada and US, while PCB concentrations in fish were, on average, about 4-150 times lower on Tibet than at other mountain areas. The transport and fate of contaminants in the Plateau are significantly influenced by the unique climatological and meteorological conditions, particularly by the summer Indian monsoon and winter westerly jet stream.
\end{abstract}

(c) 2010 Elsevier Ltd. All rights reserved.

\section{Introduction}

Persistent organic pollutants (POPs) such as polychlorinated biphenyls (PCBs) and organochlorine pesticides (OCPs) are of high concern, not only because of their detrimental health effects but also because they are persistent and semi-volatile, thus able to travel long distances and distribute globally. Long-range atmospheric transport (LRAT) is a primary global transport pathway for POPs (Wania and Mackay, 1994). In warm regions, POPs tend to evaporate into the atmosphere, and the transport is often directed towards the colder polar regions where they are efficiently scavenged from the atmosphere. Similarly, low temperatures in alpine regions could allow high mountains to act as cold condensers and thus influence the global transport of POPs (Daly and Wania, 2005). In Europe and North America, recent research has shown evidence of cold trapping in alpine regions for various airborne pollutants (Daly and Wania, 2005; Blais et al., 1998).

\footnotetext{
* Corresponding author. Tel.: +8610 62849334; fax: +861062849179.

E-mail address: gbjiang@rcees.ac.cn (G. Jiang).
}

The Tibetan Plateau (the Plateau) lies between the Himalayan range to the south and the Taklamakan Desert to the north. With an area of 2.5 million square kilometers and an average altitude over $4000 \mathrm{~m}$ above sea level (a.s.l.), the Plateau is the largest and highest plateau in the world. It is characterized by harsh climate featuring dramatic elevational temperature gradient and monsoon affected air movement and precipitation patterns. With sparse human population and minimal industrial activity, atmospheric transport is essentially the only source of POPs to most areas of the Plateau. Recent work showed an increase in some contaminants in conifer needles with increasing altitude along the northern slope of the central Himalayas and the southeast Tibetan mountains (Wang et al., 2006; Yang et al., 2008). These results are in accordance with the observation for the Canadian Rocky Mountains by Blais et al. (1998) and several other studies summarized by Daly and Wania (2005). Such an altitudinal trend can be confounded by other influencing factors such as proximity to sources, directions of diurnal and seasonal airflow, and the topographic feature of the sampling locations.

Alpine lakes are unique depositories of long-range transported contaminants. The lakes on the Plateau are generally characterized 
by low temperature, low dissolved organic carbon (DOC) and low nutrient level (Xiang and Zheng, 1989). In these lakes, the food chain is generally short and simple compared with the lowland aquatic ecosystems. The fish inhabiting the lakes often have higher lipid storage, longer lives and slower growth rate than those in lowland lakes (Wu and Wu, 1992). Such fish might be sensitive to long-term accumulation of persistent pollutants and can be used as an important environmental compartment for transport studies in remote areas (Demers et al., 2007).

In this study, fish samples were collected from eight alpine lakes across the entire Plateau. Concentrations of PCBs and OCPs including dichlorodiphenyltrichloroethane and its metabolites (DDTs), hexachlorocyclohexanes (HCHs) and hexachlorobenzene (HCB) were quantified in the muscle of 60 fish samples. The contaminant levels, congener profiles and dominant factors influencing on the spatial distribution of POPs in the fish were examined.

\section{Experimental section}

\subsection{Sample collection}

The sampling locations are shown in Fig. 1, and the related geographic information is summarized in Table 1 . The eight alpine lakes are located on the Plateau between latitudes $28.9^{\circ} \mathrm{N}$ and $37.3^{\circ} \mathrm{N}$, and longitudes $79.9^{\circ} \mathrm{E}$ and $100.3^{\circ} \mathrm{E}$, with elevations ranging from 2813 to $4718 \mathrm{~m}$ above sea level (a.s.l.). All studied lakes were of natural origin and situated far from known pollution sources. Fish samples were collected using fishing nets in August 2007 (except Co Na Lake and Keluke Lake, which were sampled in August 2006). Each fish was individually wrapped in solvent-rinsed and baked foil and placed into a self-sealed polyethylene bag. Clean nitrile gloves were used when handling samples. Most fish species collected belonged to the same family Cyprinidae and subfamily Schizothoracinae, which are unique in the Plateau (Wu and $\mathrm{Wu}, 1992$ ). All the fish taken from a single lake were of the same species. Samples were stored in an ice-cooled box during transportation.

\subsection{Fish characterization}

Each fish was treated as an individual sample except for fish from Co Na Lake and Keluke Lake. These two lakes were sampled during the early stage of this work, and three fish from each of these two lakes were pooled to form a composite sample for the lake. For each sample, muscle tissue was homogenized and freeze-dried, and the subsamples were kept at $-20^{\circ} \mathrm{C}$ until chemical analysis. The actual age of each fish was determined by counting the growth ring of the vertebra of the fish. The lipid content was determined gravimetrically. The conditioning factor, which is the ratio of weight $(\mathrm{cg}: \mathrm{g} \times 100)$ to cubic length $\left(\mathrm{cm}^{3}\right)$, was measured to compare the relative health status of individual fish from each lake.

\subsection{Chemical analysis}

The analytical procedure for OCPs was similar to our previously established method with some modifications (Yang et al., 2007). One gram of freeze-dried sample was mixed with sodium sulfate and extracted on a Dionex 300 accelerated solvent extractor (ASE) in 1:1 (v/v) dichloromethane:hexane. Suitable amounts of two surrogate standards, 2,4,5,6-tetrachloro-m-xylene (TMX, $1 \mathrm{ng}$ ) and PCB209 (5 ng) were added. Lipid content was determined gravimetrically using $20 \%$ of the extract. The other extract was subsequently concentrated on a rotary evaporator and subjected to clean up on a glass column (12 mm i.d.) packed with $8 \mathrm{~g}$ of activated

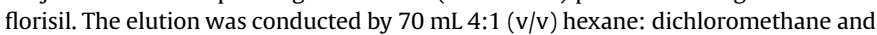
finally concentrated to about $0.5 \mathrm{~mL}$ by a gentle stream of nitrogen gas. Thirteen kinds of OCPs, including $\alpha-, \beta-, \gamma-, \delta$-HCH, HCB, $p, p^{\prime}$-DDE, $o, p^{\prime}$-DDE, $p, p^{\prime}$-DDD, $o, p^{\prime}$-DDD, $o, p^{\prime}$-DDT and $p, p^{\prime}$-DDT were analyzed by an Agilent $6890 \mathrm{~N}$ gas chromatography (GC) equipped with a ${ }^{63} \mathrm{Ni}$ electron capture detector (micro-ECD) (USA). A DB-5 fused silica capillary column ( $30 \mathrm{~m}$ length $\times 0.25 \mathrm{~mm}$ i.d.) coated with $5 \%$ dimethylsiloxane (film thickness $0.25 \mu \mathrm{m}$ ) was used for separation. The oven temperature was held at $80{ }^{\circ} \mathrm{C}$ for $1 \mathrm{~min}$, ramped at $10{ }^{\circ} \mathrm{C} / \mathrm{min}$ to $180{ }^{\circ} \mathrm{C}$, held for $5 \mathrm{~min}$, then at $2{ }^{\circ} \mathrm{C} / \mathrm{min}$ to $215^{\circ} \mathrm{C}$, held for $4 \mathrm{~min}$, and finally at $25^{\circ} \mathrm{C} / \mathrm{min}$ to $280^{\circ} \mathrm{C}$ and held for $15 \mathrm{~min}$. The temperatures of injector and detector were $230{ }^{\circ} \mathrm{C}$ and

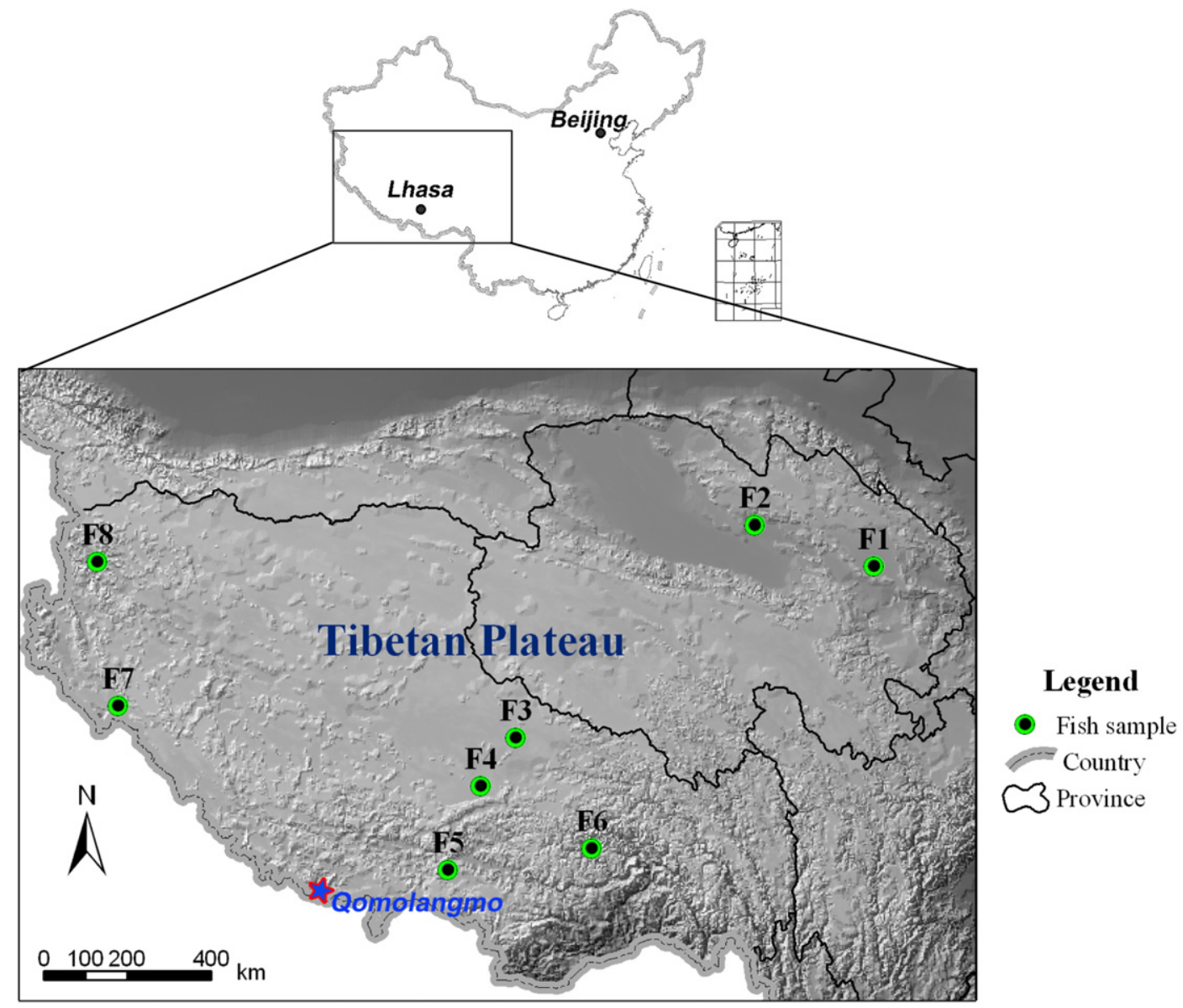

Fig. 1. The study area and sampling sites (F1: Qinghai; F2: Keluke; F3: Co Na; F4: Nam Co; F5: Yamdro; F6: Basum; F7: Manasarovar; F8: Palgon). 
Table 1

Geographical position and information related to the samples.

\begin{tabular}{|c|c|c|c|c|c|c|c|c|c|c|c|}
\hline Lake & $\begin{array}{l}\text { Latitude } \\
(\mathrm{N})\end{array}$ & $\begin{array}{l}\text { Longitude } \\
\text { (E) }\end{array}$ & $\begin{array}{l}\text { Altitude }^{a} \\
(\mathrm{~m})\end{array}$ & $\begin{array}{l}\text { Temp. } \\
\left({ }^{\circ} \mathrm{C}\right)^{\mathrm{b}, \mathrm{c}}\end{array}$ & $\begin{array}{l}\text { Precipitation } \\
(\mathrm{mm} / \mathrm{yr})^{\mathrm{c}}\end{array}$ & $\begin{array}{l}\text { No. of } \\
\text { fish }\end{array}$ & Species & $\operatorname{Age}^{\mathrm{d}}$ & $\begin{array}{l}\text { Conditioning } \\
\text { factor }\left(\mathrm{cg} / \mathrm{cm}^{3}\right)\end{array}$ & $\begin{array}{l}\text { Lipid in } \\
\text { muscle (\%) }\end{array}$ & $\begin{array}{l}\text { Water in } \\
\text { muscle (\%) }\end{array}$ \\
\hline Qinghai & $36^{\circ} 43.022^{\prime}$ & $100^{\circ} 15.101^{\prime}$ & 3225 & 1.2 & 337 & 7 & $\begin{array}{l}\text { Gymnocypris } \\
\text { przewalskii }\end{array}$ & $-^{\mathrm{e}}$ & - & $2.70 \pm 1.91$ & $75.9 \pm 2.2$ \\
\hline Keluke & $37^{\circ} 17.162^{\prime}$ & $96^{\circ} 52.926^{\prime}$ & 2813 & 3.7 & 176 & 3 & Carassius auratus & - & $1.47 \pm 0.04$ & 1.69 & 79.9 \\
\hline $\mathrm{Co} \mathrm{Na}$ & $32^{\circ} 02.021^{\prime}$ & $91^{\circ} 30.805^{\prime}$ & 4595 & -6 to -4 & 400 & 3 & $\begin{array}{l}\text { Gymoncypris } \\
\text { microcephalus }\end{array}$ & $9.7 \pm 0.6$ & $1.05 \pm 0.13$ & 2.59 & 80.0 \\
\hline Nam Co & $30^{\circ} 53.643^{\prime}$ & $90^{\circ} 52.095^{\prime}$ & 4718 & 0 & 790 & 10 & $\begin{array}{l}\text { Gymoncypris } \\
\text { microcephalus }\end{array}$ & $10.4 \pm 3.1$ & $1.03 \pm 0.11$ & $1.73 \pm 0.91$ & $81.9 \pm 2.2$ \\
\hline Yamdro & $28^{\circ} 59.475^{\prime}$ & $90^{\circ} 28.351^{\prime}$ & 4441 & 2.4 & 373 & 17 & $\begin{array}{l}\text { Gymoncypris } \\
\text { waddellii }\end{array}$ & $9.1 \pm 2.1$ & $1.30 \pm 0.12$ & $1.62 \pm 0.80$ & $81.5 \pm 2.1$ \\
\hline Basum & $30^{\circ} 00.210^{\prime}$ & $93^{\circ} 54.376^{\prime}$ & 3538 & 6.0 & $600-700$ & 6 & $\begin{array}{l}\text { Racoma biddulphi } \\
\text { Gunther }\end{array}$ & $7.3 \pm 1.0$ & $1.06 \pm 0.14$ & $4.94 \pm 2.26$ & $77.9 \pm 3.0$ \\
\hline Manasarovar & $30^{\circ} 43.017^{\prime}$ & $81^{\circ} 27.670^{\prime}$ & 4588 & 2.0 & 169 & 7 & $\begin{array}{l}\text { Gymoncypris } \\
\text { waddellii }\end{array}$ & $6.3 \pm 0.8$ & $1.07 \pm 0.18$ & $1.58 \pm 0.70$ & $83.2 \pm 1.0$ \\
\hline Palgon & $33^{\circ} 31.191^{\prime}$ & $79^{\circ} 52.881^{\prime}$ & 4242 & -4 to -2 & 61 & 7 & Racoma tibetanus & $9.9 \pm 2.2$ & $1.01 \pm 0.09$ & $2.64 \pm 1.55$ & $80.6 \pm 1.9$ \\
\hline
\end{tabular}

a Meters above sea level.

b Average annual temperature.

c Data from reference (Xiang and Zheng, 1989).

d Average value $( \pm \mathrm{SD})$ of the fish analyzed in each lake.

e Not determined.

$330^{\circ} \mathrm{C}$, respectively. One microliter of the extract was injected in the splitless mode. High purity nitrogen was used as the carrier gas with a flow rate of $1.0 \mathrm{~mL} / \mathrm{min}$ and the make-up gas was controlled at $59 \mathrm{~mL} / \mathrm{min}$. Pentachloronitrobenzene (PCNB) was added as internal standard before GC injection, in order to quantify the concentration and recoveries of surrogates (TMX and PCB209). The reported concentrations of $\alpha-, \beta-, \gamma-, \delta-H C H, H C B$ are after corrections based on the recovery of TMX; and concentrations of $p, p^{\prime}$-DDE, $o, p^{\prime}$-DDE, $p, p^{\prime}$-DDD, $o, p^{\prime}$-DDD, $o, p^{\prime}$-DDT, and $p, p^{\prime}$-DDT were corrected using the recovery of $\mathrm{PCB} 209$. The main peaks were confirmed in selected samples by a Finnigan Polaris-Q GC-MS-MS (USA). For each set of six samples, a procedural blank and a spiked sample with standards were run to check for the interference and cross-contamination. The inlet degradation of DDT was checked daily and the breakdown was less than $5 \%$. The method detection limits (MDLs) were described as 3:1 signal versus noise value $(S / N)$. The MDLs ranged from $0.019 \mathrm{ng} / \mathrm{g}$ for $\alpha-\mathrm{HCH}$ to $0.055 \mathrm{ng} / \mathrm{g}$ for $p, p^{\prime}$-DDT. The spiked recoveries were in the range of $88-103 \%$ and analytical measurements were blank corrected prior to recovery efficiency corrections. The relative standard derivation (RSD) values with five times repeatedly determined were less than $13 \%$.

PCBs were analyzed by isotope dilution method. The procedure of PCBs analysis was similar to the method described by Y.W. Wang et al. (2007). One gram of freezedried sample was spiked with ${ }^{13} \mathrm{C}$-labled PCBs extracted by the ASE using a mixture of $1: 1(\mathrm{v} / \mathrm{v})$ dichloromethane:hexane. Then about $10 \mathrm{~g}$ of acidic silica (30\% fume sulfuric acid, w/w) was added to the extract to remove lipid. The extract was concentrated and subjected to clean up using a multilayered silica gel column, which was packed from bottom to top with $1 \mathrm{~g}$ of activated silica, $4 \mathrm{~g}$ of basic silica $(1.2 \% \mathrm{w} / \mathrm{w}), 1 \mathrm{~g}$ of activated silica, $8 \mathrm{~g}$ of acid silica $(30 \% \mathrm{w} / \mathrm{w}), 1 \mathrm{~g}$ of activated silica, and $4 \mathrm{~g}$ of anhydrous sodium sulfate. The column was pre-washed by $100 \mathrm{~mL}$ hexane before use. The elution was accomplished by $100 \mathrm{~mL} 50 \%$ dichloromethane in hexane and the solvent was changed to $20 \mu \mathrm{L}$ nonane in a minivial. Before instrumental analysis, ${ }^{13} \mathrm{C}$-labeled internal standards were added and mixed completely. A total of 25 PCB congeners, including 12 coplanar congeners (CBs 77, 81, 105, 114, 118, 123, 126, $156,157,167,169$, and 189), six indicator congeners (CBs 28, 52, 101, 138, 153, and 180 ), and other congeners (CBs 3, 15, 19, 202, 205, 208, and 209) were analyzed. The instrumental analysis was performed on an Agilent 6890 gas chromatography coupled with high-resolution mass spectrometer (HRMS) (Waters Micromass, Manchester, UK) with an electron impact (EI) ion source. One microliter extract was injected in splitless mode. DB-5 capillary columns $(60 \mathrm{~m} \times 250 \mu \mathrm{m}$ i.d. $\times 0.25 \mu \mathrm{m}$ film thickness) were used for separation. Helium was used as carrier gas with flow rate of $1.2 \mathrm{~mL} / \mathrm{min}$. Each batch of 11 samples includes one procedural blank. The mean concentration of the PCBs was $0.10 \mathrm{ng} / \mathrm{sample}$ and the dominant congener was CB28. The mean recoveries for ${ }^{13} \mathrm{C}$-labeled surrogate PCBs were $60-115 \%$.

\section{Results and discussion}

\subsection{Fish characteristics}

Average age of fish in each lake ranges between 6.3 (Manasarovar) and $10.4 \mathrm{yr}$ (Nam Co) (Table 1). Length of individual fish ranged from 200 to $470 \mathrm{~mm}$, and weighed between 65 and $899 \mathrm{~g}$. The lake average fish conditioning factor ranged from 1.01 to $1.47 \mathrm{cg} / \mathrm{cm}^{3}$ (mean $1.12 \mathrm{cg} / \mathrm{cm}^{3}$ ), while lake-averaged fish lipid content varied from $1.58 \%$ to $4.94 \%$ (Table 1 ) and was not correlated with elevation of the locations. There was no correlation between age, conditioning factor or lipid content and elevation $(P>0.05)$.

\subsection{Concentrations and patterns}

Dry weight ( $\mathrm{dw}$ ) based lake average concentrations of the POPs in fish muscle are summarized in Table 2. Lipid normalized concentrations and composition profiles at different sampling sites are presented in Fig. 2.

Average concentrations of $\sum \mathrm{HCH}$ and $\mathrm{HCB}$ are $2.5 \pm 1.4 \mathrm{ng} / \mathrm{g} \mathrm{dw}$ and $1.1 \pm 1.0 \mathrm{ng} / \mathrm{g} \mathrm{dw}$, respectively. The concentrations of $\alpha-, \gamma$ - and $\beta-\mathrm{HCH}$ were from 0.34 to $1.8 \mathrm{ng} / \mathrm{g} \mathrm{dw}$ (mean $0.88 \mathrm{ng} / \mathrm{g} \mathrm{dw}$ ), from 0.37 to $1.6 \mathrm{ng} / \mathrm{g} \mathrm{dw}$ (mean $0.82 \mathrm{ng} / \mathrm{g} \mathrm{dw}$ ), and from 0.35 to $1.1 \mathrm{ng} /$ $\mathrm{g} \mathrm{dw}$ (mean $0.70 \mathrm{ng} / \mathrm{g} \mathrm{dw}$ ), respectively. The concentrations of contaminants were transformed to wet weight basis in order to have a direct comparison with other remote mountain fish (Table 3). HCB concentrations in Tibetan fish were similar to Western US Parks (Ackerman et al., 2008) or slightly lower than the Canada Rocky (Demers et al., 2007) and European mountain fish (Vives et al., 2004; Blais et al., 2006; Schmid et al., 2007). $\sum \mathrm{HCH}$ in Tibetan fish were similar to European and Canada Rocky mountain fish, but higher than Western US mountain fish. Technical $\mathrm{HCH}$ usually contains $55-80 \%$ of $\alpha-\mathrm{HCH}, 5-14 \%$ of $\beta-\mathrm{HCH}, 8-15 \%$ of $\gamma-\mathrm{HCH}$ and $2-16 \%$ of $\delta-\mathrm{HCH}$ (Willett et al., 1998). In our samples, the lake-averaged concentration of $\alpha-, \gamma-, \beta$ - and $\delta$ - $\mathrm{HCH}$ were found to

Table 2

Lake average concentration (ng/g dry weight) in fish muscle in the Tibetan Plateau (mean \pm standard deviation).

\begin{tabular}{lllll}
\hline Lakes & $\mathrm{HCB}$ & $\Sigma \mathrm{HCHs}^{\mathrm{b}}$ & $\Sigma \mathrm{DDTs}^{\mathrm{c}}$ & $\Sigma \mathrm{PCB}^{\mathrm{d}}$ \\
\hline Qinghai & $1.07 \pm 0.73$ & $1.61 \pm 0.23$ & $10.02 \pm 0.79$ & $4.04 \pm 1.68$ \\
Keluke $^{\mathrm{a}}$ & 0.60 & 1.34 & 4.19 & 0.44 \\
Co Na $^{\mathrm{a}}$ & 3.64 & 3.91 & 10.79 & 0.91 \\
Nam Co & $0.77 \pm 0.73$ & $4.03 \pm 1.71$ & $20.66 \pm 7.25$ & $2.01 \pm 0.96$ \\
Yamdro & $0.64 \pm 0.23$ & $2.75 \pm 1.03$ & $14.38 \pm 7.08$ & $0.32 \pm 0.18$ \\
Basum & $1.11 \pm 0.38$ & $4.17 \pm 1.64$ & $34.55 \pm 5.43$ & $2.41 \pm 1.18$ \\
Manasarovar & $0.46 \pm 0.08$ & $1.76 \pm 0.96$ & $43.28 \pm 16.63$ & $2.61 \pm 0.85$ \\
Palgon & $0.66 \pm 0.30$ & $2.09 \pm 1.16$ & $12.60 \pm 19.73$ & $0.34 \pm 0.27$ \\
\hline
\end{tabular}

a Pooled sample analysis.

b Sum concentration of $\alpha-, \beta-, \gamma-$ and $\delta-\mathrm{HCH}$.

c Sum concentration of $p, p^{\prime}-\mathrm{DDE}, o, p^{\prime}-\mathrm{DDE}, p, p^{\prime}-\mathrm{DDD}, o, p^{\prime}-\mathrm{DDD}, o, p^{\prime}-\mathrm{DDT}$ and $p, p^{\prime}-$ DDT.

d Sum concentration of CBs 3, 15, 19, 28, 52, 77, 81, 101, 105, 114, 118, 123, 126, 138, 156, 153, 157, 167, 169, 180, 189, 202, 205, 208 and 209. 
A
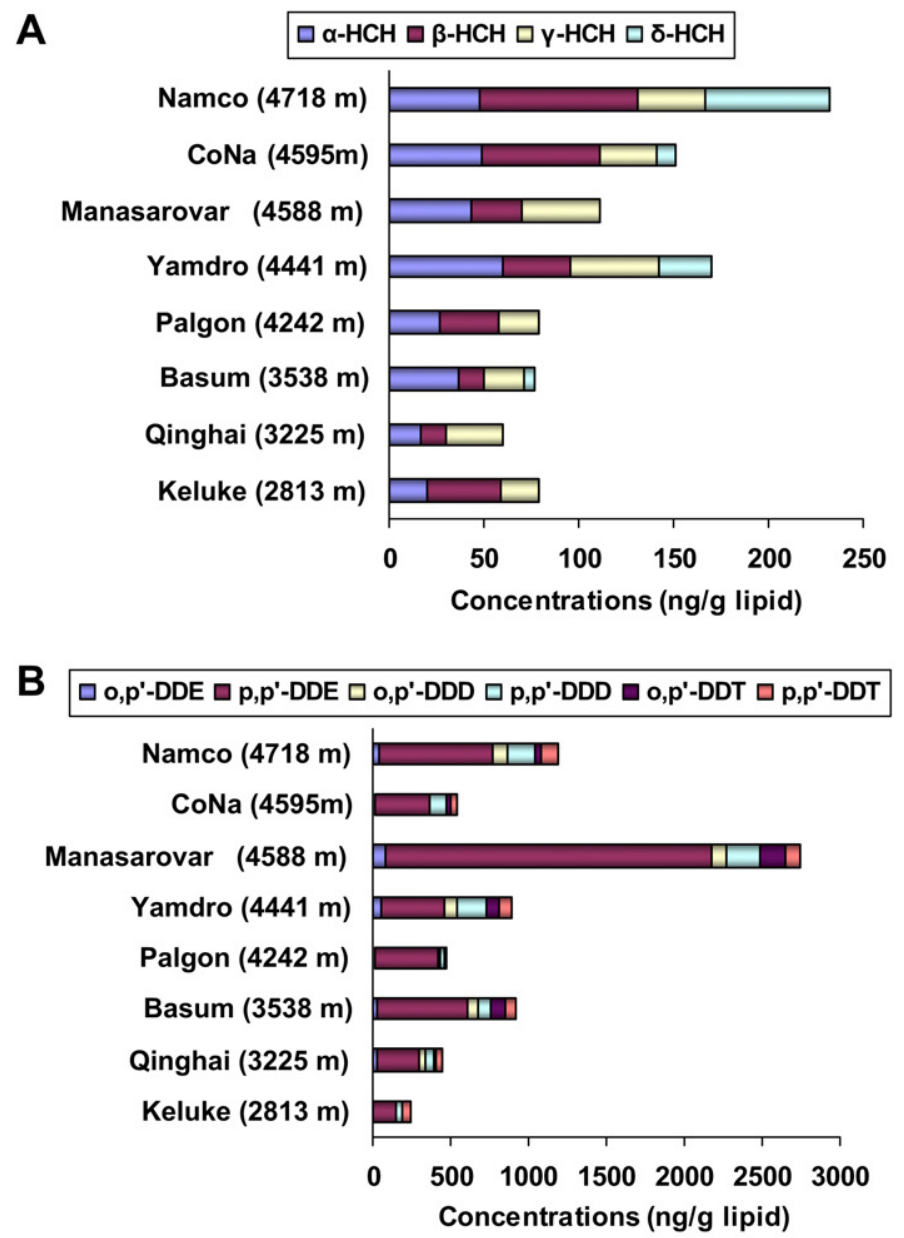

\begin{tabular}{llllllll|}
\hline$\square$ PCB-3 & $\square$ PCB-15 & $\square$ PCB-19 & $\square$ PCB-28 & $\square$ PCB-52 & $\square$ PCB-77 & $\square$ PCB-81 \\
$\square$ PCB-101 & $\square$ PCB-105 & $\square$ PCB-114 & $\square$ PCB-118 & $\square$ PCB-123 & $\square$ PCB-126 & $\square$ PCB-138 \\
$\square$ PCB-153 & $\square$ PCB-156 & $\square$ PCB-157 & $\square$ PCB-167 & $\square$ PCB-169 & ख PCB-180 & $\square$ PCB-189 \\
$\square$ PCB-202 & $\square$ PCB-205 & $\square$ PCB-208 & $\square$ PCB-209 & & & \\
\hline
\end{tabular}

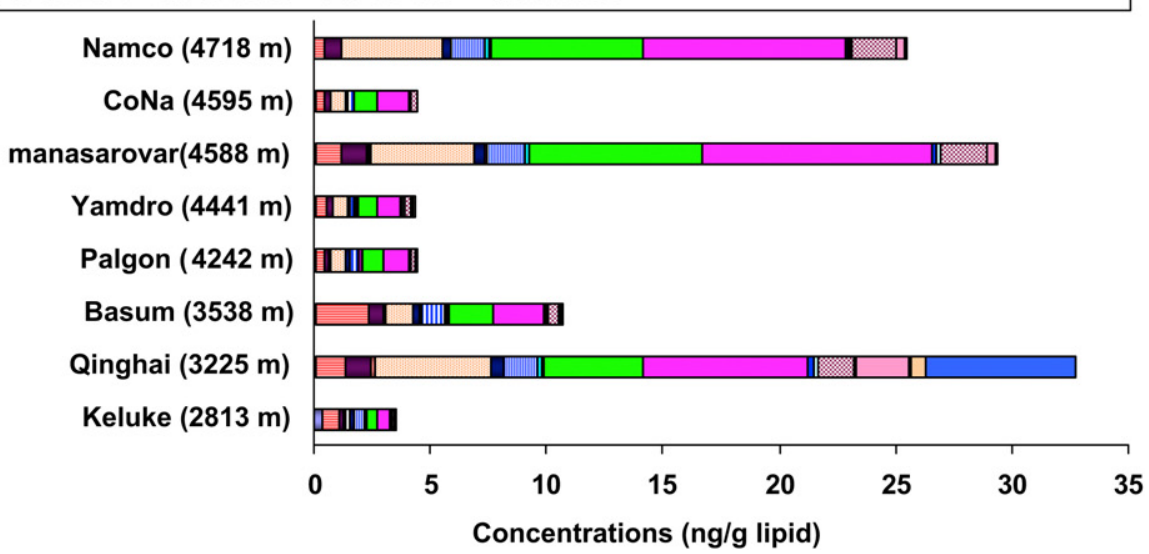

Fig. 2. Lipid normalized concentrations and composition profiles of POPs in Tibetan Plateau lakes. (A) HCHs; (B) DDTs; (C) PCBs

contribute $20-49 \%, 17-49 \%, 15-49 \%$ and $0-28 \%$, respectively, to $\sum \mathrm{HCH}$. The contribution of $\beta-\mathrm{HCH}$ was elevated about 3 times compared to the composition of the technical HCH. $\beta-\mathrm{HCH}$ is more stable and resistant to microbial degradation compared with other isomers. In addition, the $\alpha$ - and $\gamma$-HCHs may be transformed to $\beta-\mathrm{HCH}$ in the environment (Walker, 1999). The ratio of $\alpha-/ \gamma-\mathrm{HCH}$ isomers ranges between 0.7 and 2.1, significantly lower than the range of $4-15$ in technical $\mathrm{HCH}$. Considering lindane $(>90 \% \gamma-\mathrm{HCH})$ is still being used in regions surrounding the plateau, the present low $\alpha / \gamma-\mathrm{HCH}$ ratio indicates the use of lindane as a potential main source.

Concentrations of $\sum$ DDT were much higher than $\sum \mathrm{HCH}$ in the fish muscle, with a mean of $18 \pm 14 \mathrm{ng} / \mathrm{g} \mathrm{dw}$. $\sum$ DDT in Tibetan fish were, on average, comparable to Western US Parks and Canada Rocky mountain fish, but 3-5 times lower than the Europe a mountain fish (Table 3). Technical DDT usually contains about 85\% 
Table 3

Comparison of contaminants concentrations in fish muscle from remote mountain lakes (ng/g ww).

\begin{tabular}{|c|c|c|c|c|c|c|c|c|}
\hline \multirow[t]{2}{*}{ Location } & \multicolumn{4}{|c|}{ Concentration (average, range) } & \multirow[t]{2}{*}{$N$} & \multirow[t]{2}{*}{ Altitude $^{a}$} & \multirow[t]{2}{*}{ Year } & \multirow[t]{2}{*}{ References } \\
\hline & HCB & $\sum \mathrm{HCH}$ & $\sum \mathrm{DDT}$ & $\sum \mathrm{PCB}$ & & & & \\
\hline Tibetan Plateau & $0.21(0.08-0.55)$ & $0.55(0.27-0.98)$ & $4.0(0.84-10.1)$ & $0.32(0.06-0.97)$ & 62 & $2813-4718$ & $2006-2007$ & This study \\
\hline European mountains & $0.42(0.14-1.0)$ & $0.54(0.1-1.6)$ & $19(0.25-65)$ & $6.3(0.68-17)^{\mathrm{b}}$ & 163 & $436-2799$ & $2000-2001$ & Vives et al. (2004) \\
\hline French Pyrénées & 0.26 & $n a^{\mathrm{c}}$ & na & 50 & 37 & $450-2492$ & 2001 & Blais et al. (2006) \\
\hline Switzerland & $0.43(0.15-1.1)$ & na & $12(6.6-22)$ & $18(7.5-40)^{\mathrm{d}}$ & 79 & $2062-2631$ & 2003 & Schmid et al. (2007) \\
\hline $\begin{array}{l}\text { Canada Rocky } \\
\text { mountain }\end{array}$ & $0.35(0.014-1.9)$ & $0.25(0.023-1.2)$ & $5.6(0.17-52)$ & $7.7(0.5-59)$ & 91 & $760-2360$ & $\begin{array}{l}1997,2001, \\
2003\end{array}$ & Demers et al. (2007) \\
\hline Western US Parks & $0.26(0.01-1.3)$ & $0.063(0.001-0.52)$ & $4.3(0.16-34)$ & $1.1(0.1-4.6)^{\mathrm{e}}$ & 136 & $430-3030$ & $2003-2005$ & Ackerman et al. (2008) \\
\hline US Nevada & na & na & na & $9(3-14)^{\mathrm{f}}$ & 8 & 2384 & 1995 & Datta et al. (1998) \\
\hline
\end{tabular}

${ }^{\text {a }} \mathrm{m}$, above sea level.

b $\sum$ PCB $=$ PCB28, 52, 101, 118, 153, 138 and 180.

c Not available.

d $\sum$ PCB $=$ PCB28, 52, 101, 118, 153, 138, 180 and 118.

e $\sum P C B=P C B 74,101,118,138,153,183$ and 187.

f $\sum P C B=$ PCB118, 146, 180, 105, 132, 153, 138, 163, 149 and 107.

$p, p^{\prime}$-DDT and 15\% o,p'-DDT (o,p'-DDT:p,p'-DDT = 0.18). In this work, $o, p^{\prime}$-DDT was detected at much higher percentage $\left(o, p^{\prime}\right.$-DDT: $p$, $p^{\prime}$-DDT $\left.=0.81 \pm 0.55\right)$ compared with the original technical DDT composition. Recent research indicated pesticide dicofol is characterized by high ratio of $o, p^{\prime}$-DDT to $p, p^{\prime}$-DDT (about 7.0) (Qiu et al., 2005). The current use of dicofol in regions surrounding the Plateau (such as India and China) may have contributed to the current DDT profiles found in the fish. The dechlorination products of $p, p^{\prime}$-DDT and $o, p^{\prime}$-DDT are $p, p^{\prime}$-DDD and $o, p^{\prime}$-DDD under reducing conditions, and $p, p^{\prime}$-DDE and $o, p^{\prime}$-DDE under aerobic conditions (Garrison et al., 2000). In this work, $p, p^{\prime}$-DDE was found to be the most abundant in the DDT family (Fig. 2B), and the observed ratio of DDT/ $(\mathrm{DDE}+\mathrm{DDD})$ is low (mean 0.20), indicating aged DDT pollution. According to the available concentration of DDTs in Yamdro lake water (Zhang et al., 2003), the bioconcentration factor of DDT by fish according to our result was estimated to be as high as 10,000 . The accumulation of persistent and lipophilic contaminants is likely to be exacerbated by fish in alpine lakes due to their higher lipid storage, longer lives and slower growth rate.

Average concentration of $\sum_{25} \mathrm{PCB}$ was $1.64 \pm 1.35 \mathrm{ng} / \mathrm{g} \mathrm{dw}$, which was comparable with the concentration of HCB, but obviously lower than the concentration of $\sum \mathrm{HCH}$ and $\sum$ DDT. The quantified congeners were quite different in the compared sites (Table 3). Although quantified congeners in our study were the most $\left(\sum{ }_{25} \mathrm{PCB}\right)$, the $\sum \mathrm{PCB}$ in Tibetan fish were, on average, about 4-150 times lower than these compared mountain fish. PCB153 and PCB138 are the main congeners in most samples (Fig. 2C), varying from 14 to $34 \%$ and from 14 to $23 \%$ of $\Sigma_{25} \mathrm{PCB}$, respectively. A strong linear relationship was found between indicator $\Sigma_{6} \mathrm{PCB}$ (CBs 28, 52, 101, 138, 153 and 180) and $\Sigma_{25} \mathrm{PCB}$ (coefficient $R^{2}=0.91$, $P<0.05)$. Penta and hexa-CBs were the predominant PCB congeners, ranging from 22 to $31 \%$ (mean 24\%) and from 31 to $61 \%$ (mean $47 \%$ ) of $\Sigma_{25} \mathrm{PCB}$, respectively (see Supplementary Fig. S1). Although correlations between fish age and lake-wide average concentrations were not significant $(p>0.05)$ for most pollutants, positive linear correlations were observed between age and concentrations of heavier PCBs (octaPCBs: $R^{2}=0.314$; nonaPCBs: $R^{2}=0.282,<0.05$, $N=17$ ) in individual fish in Lake Yamdro.

\subsection{Spatial variations}

Table 4 showed the multiple regressions for log-transformed concentrations (lipid wt, $N=56$ ) with the temperature, precipitation, longitude and latitude of the sampling sites. The results indicated that the four parameters are major factors in explaining the variance in contaminant concentrations in fish sample and was correlated 11 of 14 contaminant class considered in Table $4(P<0.05)$.

Temperature was usually regarded as the predominant factor controlling the distribution of POPs in mountains (Wania and Westgate, 2008). Our results indicate HCHs and HCB concentrations correlate with the reciprocal of the absolute temperature $(P<0.05)$ or correlate with the elevations of the sampling sites (HCHs, Fig. 2A). Previous studies have shown that in the mountain slopes of the Plateau, such as Himalayas and southeast Tibet,

Table 4

Multiple regressions for log-transformed concentrations (lipid wt, $\mathrm{N}=56$ ) with the temperature, precipitation, longitude and latitude of the sampling sites.

\begin{tabular}{|c|c|c|c|c|c|c|c|}
\hline \multirow[t]{2}{*}{ Chemical } & \multirow[b]{2}{*}{ Constant } & \multirow[b]{2}{*}{$1 / \mathrm{T}$} & \multirow{2}{*}{$\frac{\text { Coefficient } \pm \text { SE }}{\text { Precipitation }^{\mathrm{a}}}$} & \multirow[b]{2}{*}{ Longitude $\left({ }^{\circ} \mathrm{E}\right)$} & \multirow[b]{2}{*}{ Latitude $\left({ }^{\circ} \mathrm{N}\right)$} & \multirow[t]{2}{*}{$R^{2}$} & \multirow[t]{2}{*}{$P$} \\
\hline & & & & & & & \\
\hline$\alpha-\mathrm{HCH}$ & $-10.44 \pm 4.51^{*}$ & $3138 \pm 1203 *$ & $-0.250 \pm 0.178$ & $0.027 \pm 0.008^{* *}$ & $-0.075 \pm 0.017^{* *}$ & 0.321 & 0.0007 \\
\hline$\beta-\mathrm{HCH}$ & $-21.33 \pm 6.25^{* *}$ & $5465 \pm 1674 * *$ & $0.368 \pm 0.248$ & $0.029 \pm 0.011^{* *}$ & $-0.014 \pm 0.023$ & 0.457 & $<0.0001$ \\
\hline$\gamma-\mathrm{HCH}$ & $-11.62 \pm 4.48 *$ & $3393 \pm 1197^{* *}$ & $-0.382 \pm 0.184^{*}$ & $0.027 \pm 0.008^{* *}$ & $-0.068 \pm 0.017^{* *}$ & 0.267 & 0.006 \\
\hline$\sum \mathrm{HCH}$ & $-21.44 \pm 6.00^{* *}$ & $5434 \pm 1602^{* *}$ & $-0.145 \pm 0.237$ & $0.047 \pm 0.011^{* *}$ & $-0.032 \pm 0.023$ & 0.401 & $<0.0001$ \\
\hline $\mathrm{HCB}$ & $-14.42 \pm 4.02^{* *}$ & $3763 \pm 1074$ ** & $-0.258 \pm 0.159$ & $0.031 \pm 0.007^{* *}$ & $-0.036 \pm 0.015^{*}$ & 0.320 & 0.0007 \\
\hline p,p'-DDE & $22.80 \pm 8.38^{* *}$ & $-5190 \pm 2236^{*}$ & $0.617 \pm 0.331$ & $-0.035 \pm 0.015 *$ & $0.032 \pm 0.032$ & 0.175 & 0.048 \\
\hline p,p'-DDD & $2.30 \pm 7.06$ & $36.44 \pm 1885$ & $0.138 \pm 0.278$ & $-0.002 \pm 0.013$ & $-0.032 \pm 0.027$ & 0.092 & 0.337 \\
\hline o,p'-DDT & $18.00 \pm 4.71^{* *}$ & $-3985 \pm 1274^{* *}$ & $0.085 \pm 0.189$ & $-0.014 \pm 0.009$ & $-0.035 \pm 0.019$ & 0.468 & $<0.0001$ \\
\hline p,p'-DDT & $-2.70 \pm 5.01$ & $1355 \pm 1344$ & $0.312 \pm 0.206$ & $-0.009 \pm 0.010$ & $-0.011 \pm 0.020$ & 0.176 & 0.119 \\
\hline$\sum \mathrm{DDT}$ & $13.57 \pm 8.24$ & $-3223 \pm 2196$ & $0.249 \pm 0.326$ & $-0.002 \pm 0.015$ & $0.017 \pm 0.031$ & 0.098 & 0.285 \\
\hline $1-4 \mathrm{Cl}^{\mathrm{b}}$ & $26.64 \pm 9.11^{* *}$ & $-7961 \pm 2433^{* *}$ & $0.865 \pm 0.360^{*}$ & $-0.027 \pm 0.016$ & $0.142 \pm 0.034^{* *}$ & 0.345 & 0.0003 \\
\hline $5 \mathrm{Cl}^{\mathrm{b}}$ & $10.56 \pm 9.74$ & $-3431 \pm 2600$ & $1.10 \pm 0.385^{* *}$ & $-0.027 \pm 0.017$ & $0.136 \pm 0.037^{* *}$ & 0.284 & 0.002 \\
\hline $6-10 \mathrm{Cl}^{\mathrm{b}}$ & $10.08 \pm 12.23$ & $-3367 \pm 3264$ & $1.13 \pm 0.483 *$ & $-0.018 \pm 0.022$ & $0.130 \pm 0.046^{* *}$ & 0.224 & 0.013 \\
\hline$\sum \mathrm{PCB}$ & $13.56 \pm 10.43$ & $-4183 \pm 2785$ & $1.08 \pm 0.412 *$ & $-0.022 \pm 0.019$ & $0.132 \pm 0.039 * *$ & 0.269 & 0.004 \\
\hline
\end{tabular}

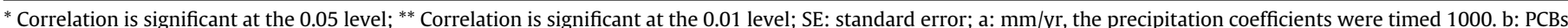

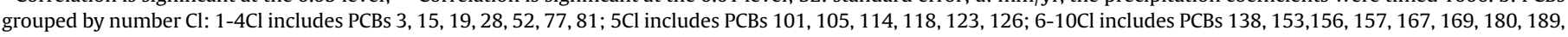
202, 205, 208, 209. 
concentrations of some POPs in soil, pine needles and spruce needles increased with increasing altitude (Wang et al., 2006, 2009; Yang et al., 2008). Such a positive altitudinal gradient of concentrations points to the overlaying atmosphere as the dominating input source for these pollutants, and suggests that the mountains in the Plateau act as a regional convergence zone, thus providing evidence of mountain cold trapping. Chen et al. (2008) also found the lighter PCBs and $\mathrm{HCHs}$ increased with the elevation in mountain soil samples in western Sichuan, China. However, for lighter PCBs $(1-4 \mathrm{Cl})$ in this study showed the different trend. The lakes situated at lower altitudes or higher temperature tends to have higher fractions of mono- and di-CBs congeners than the higher lakes (Table 4, Fig. S1). Such difference may be attribute to the locations of lakes of the plateau with very different meteorological conditions and proximity to sources. The heavier PCBs appear to be preferably enriched at higher elevation (Fig. S1). This result is consistent with the observation that less volatile congeners (with subcooled liquid vapor pressure $\leq 10^{-2.5} \mathrm{~Pa}$ ) are preferentially trapped at higher locations (Grimalt et al., 2001) and the predictions by the MountainPOP model simulations (Wania and Westgate, 2008). The lower tendency of heavier congener to re-evaporate from water into air during warm seasons may also result in their preferential accumulation over time. The preferential bioaccumulation of heavier congeners by fish at higher elevations may also be related to the lower temperature, which slows the metabolic dechlorination of PCBs in fish. Studies on mountain lakes across Europe revealed strong dependence of OCP concentration in fish on ambient air temperature of the sites as well as the proximity to sources in Central Europe (Daly and Wania, 2005; Gallego et al., 2007).

Precipitation is often believed to be efficient at capturing both particle-bound and gaseous POPs from air (Daly and Wania, 2005). F. Wang et al. (2007) also observed ten kinds of OCPs in newly deposited snow from the Mt. Everest region. However, in this study, only $\gamma-\mathrm{HCH}, 1-4 \mathrm{Cl}, 6-10 \mathrm{Cl}$ and sum of PCB were correlated with precipitation $(P<0.05$, Table 4$)$ and most of OCP contaminants didn't pass the significant test $(P>0.05)$. The transport and fate of POPs can be significantly complicated by other influencing factors such as the proximity to sources and the directions of seasonal airflow, which could be reflected by the latitudinal and longitudinal trends of pollutant concentrations. In this work, a negative correlation between logarithm of concentrations for most OCPs in fish and latitude or longitude was found (Table 4). The positive correlation of PCB with latitude suggests the lack of significant atmospheric transport of these industrial chemicals from the agriculture dominated areas south of the Plateau and also may be affected by other sources from north china (e.g. the highest PCB concentration was found in Lake Qinghai). The pathways of air mass to each sampling site were determined to assess potential source regions using backward trajectories from the hybrid single-particle Lagrangian integrated trajectory (HYSPLIT) model (www.arl.noaa. gov/ready/hysplit4.html) (see Supplementary Fig. S2). During summer (June-September), high temperature over the Indian subcontinent and the Plateau causes a low-pressure front which induces a supply of air mass over the Indian subcontinent to move into the mountain ranges of the Plateau and results in significant precipitation events (Yanai and $\mathrm{Wu}, 2005$ ). Air mass movement in the southern Plateau is controlled by the southeast wind (Sites F4-F6) and southwest wind (Site F7) arriving from the Indian continent. In contrast, in the northern (Sites F1 and F2) and northwest (Site F8) of the Plateau are prevailed by the westerly wind (Fig. S2a). During winter time the continent cools down and high-pressure drives the wind away from the Plateau and splits the westerly jet stream into two currents flowing south and north of the Plateau, and air mass movement to all the sampling sites is predominated by the westerly wind (Fig. S2b).
Sources of OCPs to the Plateau are likely to be significantly affected by the southwest or southeast air mass from Indian subcontinent. Our previous work showed a summer monsooncontrolled distribution pattern of OCPs in conifer needles in southeast Tibet (Yang et al., 2008). Zhu et al. (2004) have shown that there is a strong seasonal variation in the concentration of OCPs in an ice core from the Mt. Qomolangma region, resulted from the effects of the Indian monsoon. It is estimated that about $5 \times 10^{5}$ tones of DDT and more than $10^{6}$ tones of technical HCH have been used in India. China used about $2.7 \times 10^{5}$ tones of DDT as well as $4.9 \times 10^{6}$ tones of technical HCH from the 1950 s until its ban in 1983 (Li et al., 1998). DDT and lindane are still being used to control certain insects in some tropical and subtropical countries including India, although in lower amount than in the past (Li et al., 1998). The effect of the monsoon on air pollution in this region has been documented in other studies (Valsecchi et al., 1999; Hindman and Upadhyay, 2002), providing additional evidence of region-specific meteorological influence. These findings combined suggest that OCPs transported by air to the Plateau might mainly originate from the Indian subcontinent.

\section{Conclusion}

This work provided evidence for atmospheric transport and deposition of POPs to higher-altitude lakes in the Tibetan Plateau. The accumulation pattern of POPs by alpine lake fish and some influencing factors on spatial variations were examined. The specific mechanism for transport of POPs to the Plateau is at present not completely understood due to the limited data. Future studies on the role played by the Plateau in the global distribution, long-range transport and the fate of persistent and toxic chemicals are warranted.

\section{Acknowledgements}

Authorization and assistance were obtained from the Tibet Autonomous Environmental Protection Bureau for fish sampling. We thank Dr. Chengzhi Qin from Institute of Geographic Sciences and Natural Resources Research, CAS, for providing the sampling map. This work was jointly supported by the National Basic Research Program of China (2009CB421601) and the National Natural Science Foundation of China (40601101, 40873078, 20890111).

\section{Appendix Supplementary material}

Supplementary data associated with this article can be found in the online version at doi:10.1016/j.envpol.2010.02.004.

\section{References}

Ackerman, L.K., Schwindt, A.R., Massey Simonich, S.L., Koch, D.C., Blett, T.F., Schreck, C.B., Kent, M.L., Landers, D.H., 2008. Atmospherically deposited PBDEs, pesticides, PCBs, and PAHs in Western U.S. National Park Fish: concentrations and consumption guidelines. Environmental Science \& Technology 42, 2334-2341.

Blais, J.M., Charpentié, S., Pick, F., Kimpe, L.E., Amand, A.S., Regnault-Roger, C., 2006. Mercury, polybrominated diphenyl ether, organochlorine pesticide, and polychlorinated biphenyl concentrations in fish from lakes along an elevation transect in the French Pyrénées. Ecotoxicology \& Environmental Safety 63, 91-99.

Blais, J.M., Schindler, D.W., Muir, D.C.G., Kimpes, L.E., Donald, D.B., Rosenberg, M., 1998. Accumulation of persistent organochlorine compounds in mountains of western Canada. Nature 395, 585-588.

Chen, D.Z., Liu, W.J., Liu, X.D., Westgate, J.N., Wania, F., 2008. Cold-trapping of persistent organic pollutants in the mountain soils of western Sichuan, China. Environmental Science \& Technology 42, 9086-9091.

Daly, G.L., Wania, F., 2005. Organic contaminants in mountains. Environmental Science \& Technology 39, 385-398. 
Datta, S., McConnell, L.L., Baker, J.E., LeNoir, J., Seiber, J.N., 1998. Evidence for atmospheric transport and deposition of polychlorinated biphenyls to the Lake Tahoe Basin, California-Nevada. Environmental Science \& Technology 32, 1378-1385.

Demers, M., Kelly, E.N., Blais, J.M., Pick, F.R., Schindler, D.W., 2007. Organochlorine compounds in trout from lakes over a 1600 meter elevation gradient in the Canadian Rocky mountains. Environmental Science \& Technology 41, 2723-2729.

Gallego, E., Grimalt, J.O., Bartrons, M., Lopez, J.F., Camarero, L., Catalan, J., Stuchlik, E., Battarbee, R., 2007. Altitudinal gradients of PBDEs and PCBs in fish from European high mountain lakes. Environmental Science \& Technology 21, 2196-2202.

Garrison, A.W., Nzengung, V.A., Avants, J.K., Ellington, J.J., Jones, W.J., Rennels, D., Wolfe, N.L., 2000. Phytodegradation of $p, p^{\prime}$-DDT and the enantiomers of $o, p^{\prime}-$ DDT. Environmental Science \& Technology 34, 1663-1670.

Grimalt, J.O., Fernández, P., Berdie, L., Vilanova, R.M., Catalan, J., Psenner, R., Hofer, R., Appleby, P.G., Rosseland, B., Lien, L., Massabuau, J.C., Battarbee, R.W., 2001. Selective trapping of organochlorine compounds in mountain lakes of temperate areas. Environmental Science \& Technology 35, 2690-2697.

Hindman, E.E., Upadhyay, B.P., 2002. Air pollution transport in the Himalayas of Nepal and Tibet during the 1995-1996 dry season. Atmospheric Environment 36, 727-739.

Li, Y.F., Cai, D.J., Singh, A., 1998. Technical hexachlorocyclohexane use trends in China and their impact on the environment. Archives of Environmental Contamination and Toxicology 35, 688-697.

Qiu, X.H., Zhu, T., Yao, B., Hu, J.X., Hu, S.W., 2005. Contribution of dicofol to the current DDT pollution in China. Environmental Science \& Technology 39, 4385-4390.

Schmid, P., Kohler, M., Gujer, E., Zennegg, M., Lanfranchi, M., 2007. Persistent organic pollutants, brominated flame retardants and synthetic musks in fish from remote alpine lakes in Switzerland. Chemosphere 67, S16-S21.

Valsecchi, S., Smiraglia, C., Tartari, G., Polesello, S., 1999. Chemical composition of monsoon deposition in the Everest region. The Science of the Total Environment 226, 187-199.

Vives, I., Grimalt, J.O., Catalan, J., Rosseland, B.O., Battarbee, R.W., 2004. Influence of altitude and age in the accumulation of organochlorine compounds in fish from high mountain lakes. Environmental Science \& Technology 38, 690-698.

Walker, K., 1999. Factors influencing the distribution of lindane and other hexachlorocyclohexanes in the environment. Environmental Science \& Technology 33, 4373-4378.
Wang, F., Zhu, T., Xu, B.Q., Kang, S.C., 2007. Organochlorine pesiticides in newly deposited snow from east Rongbu Glacier in Mt. Everest region. Science in China Series D: Earth Sciences 37, 670-675.

Wang, P., Zhang, Q.H., Wang, Y.W., Wang, T., Li, X.M., Li, Y.M., Jiang, G.B., Ding, L., 2009. Altitude dependence of polychlorinated biphenyls (PCBs) and polybrominated diphenyl ethers (PBDEs) in surface soil from Tibetan Plateau, China. Chemosphere 76, 1498-1504.

Wang, X.P., Yao, T.D., Cong, Z.Y., Yan, X.L., Kang, S.C., Zhang, Y., 2006. Gradient distribution of persistent organic contaminants along northern slope of centralHimalayas, China. The Science of the Total Environment 372, 193-202.

Wang, Y.W., Li, X.M., Li, A., Wang, T., Zhang, Q.H., Wang, P., Fu, J.J., Jiang, G.B., 2007. Effect of municipal sewage treatment plant effluent on bioaccumulation of polychlorinated biphenyls and polybrominated diphenyl ethers in the recipient water. Environmental Science \& Technology 41, 6026-6032.

Wania, F., Mackay, D., 1994. Global fractionation and cold condensation of low volatility of organochlorine compounds in Polar regions. Ambio 22, 10-18.

Wania, F., Westgate, J.O., 2008. On the mechanism of mountain cold-trapping of organic chemicals. Environmental Science \& Technology 42, 9092-9098.

Willett, K.L., Ulrich, E.M., Hites, R.A., 1998. Differential toxicity and environmental fates of hexachlorocyclohexane isomers. Environmental Science \& Technology 32, 2197-2207.

Wu, Y.F., Wu, C.Z., 1992. The Fishes of the Qinghai-Xizang Plateau. Sichuan Science \& Technology Press, Chengdu, China.

Xiang, J., Zheng, M.P., 1989. Saline Lakes on the Qinghai-Tibet Plateau. Beijing Science \& Technology Press, Beijing.

Yanai, M., Wu, G.X., 2005. Effects of the Tibetan Plateau. In: Wang, B. (Ed.), The Asian Monsoon. Springer, Berlin, pp. 513-549.

Yang, R.Q., Yao, T.D., Xu, B.Q., Jiang, G.B., Xin, X.D., 2007. Accumulation features of organochlorine pesticides and heavy metals in fish from high mountain lakes and Lhasa River from the Tibetan Plateau. Environment International 33,151-156.

Yang, R.Q., Yao, T.D., Xu, B.Q., Jiang, G.B., Zheng, X.Y., 2008. Distribution of organochlorine pesticides (OCPs) in conifer needles in the southeast Tibetan Plateau. Environmental Pollution 153, 92-100.

Zhang, W.L., Zhang, G., Qi, S.H., Peng, P.A., 2003. A preliminary study of organoclorine pesticides in water and sediments from two Tibetan lakes. Geochimica 32, 363-367 (in Chinese).

Zhu, T., Li, J., Lin, W.L., Zu, B.Q., Kang, L., Yao, T.D., 2004. Observation of organochlorine pesticides in air and ice core in the Tibetan Plateau. In: Proceedings of SETAC Europe Workshop, Milan, Italy, July 1-3. 